\title{
Original
}

\section{Physical and Chemical Properties of an Extracellular Low-Molecular-Weight Substance from the Brown-Rot Basidiomycete Fomitopsis palustris}

\author{
SHOHEI KANEKO, TAEKO HIRANO, HIROMI TANAKA, \\ SHUJI ITAKURA AND AKIO ENOKI* \\ Department of Agricultural Chemistry, Faculty of Agriculture, Kinki University, \\ 3327-204 Nakamachi, Nara 631-8505, Japan
}

Received 11 October 2003/Accepted 17 December 2003

\begin{abstract}
A low-molecular-weight, extracellular substance with one-electron-oxidizing activity was isolated from wood-degrading cultures of the brown-rot basidiomycetous fungus Fomitopsis palustris. The substance was partially purified by acetone precipitation, gel-filtration chromatography on Sephadex G-50 and G-25, and DEAE-Sepharose ion-exchange chromatography. The partially-purified material was a glycopeptide composed of $(54 \%, w / w)$ protein and $(42 \%$, $\mathrm{w} / \mathrm{w})$ neutral carbohydrate, containing $(0.06 \%, \mathrm{w} / \mathrm{w}) \mathrm{Fe}$ (II) by weight. The molecular weight as estimated by Tricine-SDS-PAGE was 7,200-10,000; whereas the molecular weight as determined by size-exclusion or gel-filtration chromatography was $1,000-5,000$. The glycopeptide reduced $\mathrm{O}_{2}$ to $\mathrm{H}_{2} \mathrm{O}_{2}$ and $\mathrm{Fe}$ (III) to $\mathrm{Fe}(\mathrm{II})$, and thus could generate hydroxyl radical via a Fenton reaction. One $\mathrm{mg}$ of the partially-purified glycopeptide reduced $1.7 \mu \mathrm{mol}$ of $\mathrm{Fe}$ (III) to $\mathrm{Fe}$ (II) and contained at least $0.6 \mu \mathrm{mol}$ of $\alpha$-hydroxyketone or endiol groups. Most of the $\alpha$-hydroxyketone groups were 1-amino-2-ketoses produced by the condensation of side-chain amino groups and carbohydrate aldehydes. The function of the glycopeptide in brown-rot decay is discussed.
\end{abstract}

Key words : Fomitopsis pa/ustris/Brown-rot decay/Glycopeptide/One-electron oxidation/Hydroxyl radical.

\section{INTRODUCTION}

Although brown-rot fungi slightly degrade the lignin in wood, they preferentially degrade the polysaccharide components, leaving an amorphous, brown, crumbly residue composed largely of lignin (Filley et

${ }^{*}$ Corresponding author. Tel: +81-742-43-1511 (ext. 3311); Fax: +81-742-43-1445. E-mail: enoki@nara. kindai. ac. jp

Abbreviations: KTBA: 2-keto-4-thiomethylbutyric acid; $\cdot \mathrm{OH}$ : hydroxyl radical; T-SDS-PAGE: tricinesodium dodecyl sulfate-polyacrylamide gel electrophoresis; DMSO: dimethyl sulfoxide; SOD: superoxide dismutase; DMNA: N, N'-dimethyl-4-nitrosoaniline; TCA: trichloroacetic acid; TBA: thiobarbituric acid; 5HMF: 5-hydroxymethylfurfural al., 2002; Highley, 1987). Brown-rot fungi degrade cellulose in wood even though they lack enzymes which can attack and hydrolyze crystalline or natural cellulose. However, brown-rot fungi can transform lignin-related model compounds under conditions in which the fungi actively degrade crystalline cellulose while brown-rot fungi are unable to degrade the cellulose substrate under conditions in which the fungi are unable to transform the lignin-related compounds (Enoki et al., 1988; Hirano et al., 1997). This indicates that brown-rot fungi may possess a unique wood-degrading system that is capable of fully degrading natural cellulose and modifying lignin.

In the early stages of wood degradation by brownrot fungi, the $S_{2}$ layer of the wood cell wall is degraded extensively. However the $S_{3}$ layer adjacent to the cell lumen is less affected when it is attacked by 
fungal hyphae from the lumen (Enoki et al., 1988; Kuo et al., 1988). Fungal enzymes, such as cellulase and peroxidase, are too large to penetrate wood cell walls at early stages of degradation (Flournoy et al., 1991; Srebotnik and Messner, 1991). The oneelectron-oxidating activity in cultures of brown-rot fungi is proportional to the degradation of ligninrelated model compounds, natural cellulose substrates, and wood in the cultures. This one-electronoxidating activity appears to result from hydroxyl radicals (Enoki et al., 1989). The hydroxyl radical $(\cdot \mathrm{OH})$ is a strong oxidant that severely degrades the cellulose in wood, but does not delignify wood significantly (Chirat and Lachenal, 1997). However $\cdot \mathrm{OH}$ attacks lignin through a variety of reactions (Filley et al., 2002; Gierer et al., 1992). Some brown-rot fungi degrade lignin-related model compounds to yield relatively large amounts of the same products that are obtained when the lignin model compounds are attacked by $\cdot \mathrm{OH}$ (Espejo et al., 1990; Zohar et al., 1998). Furthermore, endoglucanases isolated from cultures of a brown-rot fungus hydrolyze very little of the cellulose in wood, unless the wood has been pretreated with $\cdot \mathrm{OH}$ (Rättö et al., 1997). These results suggest that brown-rot fungi have a unique nonenzymatic degradative system that may involve the diffusion of $\cdot \mathrm{OH}$ into secondary cell walls, with the degradation occurring at some distance from the fungal hyphae in the lumen.

An extracellular metabolite, 2,5-dimethoxy-1,4benzoquinone, has been isolated from liquid cultures of the brown-rot fungus, Gloeophyllum trabeum. This benzoquinone can reduce $\mathrm{Fe}(\mathrm{III})$ to $\mathrm{Fe}(\mathrm{II})$ and $\mathrm{O}_{2}$ to $\mathrm{H}_{2} \mathrm{O}_{2}$, thereby promoting a Fenton reaction between $\mathrm{Fe}(\mathrm{II})$ and $\mathrm{H}_{2} \mathrm{O}_{2}$ (Zohar et al., 1998). A lowmolecular-weight peptide $(<5,000)$ that is a highaffinity $\mathrm{Fe}$ (III) chelator and that can reduce Fe (III) to $\mathrm{Fe}(\mathrm{II})$ also has been isolated from culture extracts of G. trabeum (Wang and Gao, 2003).

Extracellular low-molecular-weight substances that catalyze a redox reaction between $\mathrm{O}_{2}$ and an electron donor to produce $\cdot \mathrm{OH}$ have been isolated from wooddegrading cultures of the brown-rot fungi $G$. trabeum and Fomitopsis palustris (Enoki et al., 1992; Hirano et al., 1995 and 1997). The low-molecular-weight substance from $F$. palustris cultures reduces $\mathrm{Fe}$ (III) to $\mathrm{Fe}(\mathrm{II})$ and strongly chelates Fe (II) (Hirano et al., 1995). Most of the extracellular $\cdot \mathrm{OH}$ produced in intact cultures of $F$. palustris is generated by a redox reaction between $\mathrm{O}_{2}$ and an electron donor that is catalyzed by this low-molecular-weight substance (Hirano et al., 1995). During the early stages of wood degradation by F. palustris, the low-molecular-weight substance is localized in the fungal cytoplasm, the fungal cell wall, the extracellular sheath surrounding the fungal cell wall, and throughout the wood cell wall, suggesting that it diffuses from the $S_{3}$ layer into the $S_{2}$ layer and the middle lamella (Hirano et al., 2000). Herein we report on the physical and chemical properties of this extracellular low-molecular-weight substance from cultures of $F$. palustris.

\section{MATERIALS AND METHODS}

\section{Organism}

The brown-rot fungus, F. palustris (Berk. Et Curt Murr. FRI) 0507, was used throughout this study.

\section{Culture conditions}

Basal agar medium was prepared as previously described (Enoki et al., 1988) except that the medium contained $0.2 \%$, (w/v) glucose and ten-fold concentrated trace elements. Wood meal from Japanese beech (Fagus crenata Blume) was extracted twice with acetone and dried. The wood meal $(2 \mathrm{~g})$, wetted with $1.2 \mathrm{ml}$ water, was sterilized and sprinkled evenly over the surface of the basal medium $(30 \mathrm{ml})$ in 300$\mathrm{ml}$ Erlenmeyer flasks. The cultures were inoculated with a small piece of fungal mat and incubated at 28 ${ }^{\circ} \mathrm{C}$.

\section{Isolation and partial purification of the extra- cellular substance}

After 30 days of incubation, $30 \mathrm{ml}$ of distilled water was added to the cultures. The mixtures were stirred with a glass rod and centrifuged at $10,000 \times g$ at 4 ${ }^{\circ} \mathrm{C}$ for $20 \mathrm{~min}$. The supernatants were filtered. The extracellular medium from 100 flasks was acetoneprecipitated $(70 \%, \mathrm{v} / \mathrm{v})$, as described previously (Hirano et al., 1995 and 1997). The precipitate was dissolved in $100 \mathrm{ml}$ of distilled water and centrifuged at $10,000 \times g$ for $20 \mathrm{~min}$. Aliquots $(10 \mathrm{ml})$ of the resulting supernatant were loaded on a distilled-waterequilibrated Sephadex G-50 column $(3.8 \times 60 \mathrm{~cm})$ and the column was eluted with distilled water. Fractions were collected, the absorbance at $280 \mathrm{~nm}$ was measured, and the ethylene generation from 2keto-4-thiomethylbutyric acid (KTBA) of the fractions was assayed as described below. Fractions comprising the major peak of ethylene-generating activity were pooled and lyophilized. The lyophilized material was combined and dissolved in $50 \mathrm{ml}$ of distilled water. Aliquots $(10 \mathrm{ml})$ were loaded on a distilled-waterequilibrated Sephadex G-25 column and eluted with distilled water. Fractions were collected and assayed for ethylene generation from KTBA. Fractions comprising the major peak of ethylene-generating activity were pooled and lyophilized. The lyophilized material 
was combined and dissolved in distilled water (20 $\mathrm{ml}$ ). Aliquots $(1 \mathrm{ml})$ of the solution were applied to a column of Hiprep 16/10 DEAE FF (Amersham Biosciences, Sweden), previously equilibrated with $0.02 \mathrm{M}$ Tris- $\mathrm{HCl}$ buffer ( $\mathrm{pH}$ 8.0) and eluted with a linear gradient of 0 to $2 \mathrm{M} \mathrm{NaCl}$ by fast-protein liquid chromatography (Amersham Biosciences, Sweden). Fractions containing the major peak of one-electron oxidating activity, as measured by ethylene generation from KTBA, were pooled and desalted on a column of HiTrap ${ }^{T M}$ Desalting (Amersham Biosciences, Sweden). The desalted solution was lyophilized. A final yield of $50 \mathrm{mg}$ of the extracellular one-electronoxidizing substance was obtained from 100 culture flasks.

\section{Ethylene generation from KTBA}

Ethylene generation from KTBA was measured as described previously (Enoki et al., 1989). Reaction mixtures contained $300 \mu \mathrm{l}$ of eluate, $300 \mu \mathrm{l}$ of 0.01 $\mathrm{M} \mathrm{H}_{2} \mathrm{O}_{2}, 300 \mu$ l of $0.16 \mathrm{M} \mathrm{Na}$-acetate buffer ( $\mathrm{pH} 4.5$ ), and $50 \mu \mathrm{l}$ of $0.1 \mathrm{M} \mathrm{KTBA}$. After $1 \mathrm{~h}$ at $30{ }^{\circ} \mathrm{C}, 1 \mathrm{ml}$ of gas was removed from the headspace and the ethylene concentration was measured directly by gas chromatography as described previously Enoki et al., 1989).

\section{Electrophoresis}

Sample preparation and Tricine-sodium dodecyl sulfate-polyacrylamide gel electrophoreses (TricineSDS-PAGE) were performed as described by Schägger and Jagow (1987). The slab gels $(0.75 \mathrm{~mm}$ thick) consisted of three sections: a $15-\mathrm{cm}$ separation gel (16.5\% T, 3\% C), a $3-\mathrm{cm}$ spacer gel (10\% $\mathrm{T}, 3 \% \mathrm{C})$, and a 2 -cm stacking gel ( $4 \% \mathrm{~T}, 3 \% \mathrm{C}) . \mathrm{T}$ denotes the total percentage concentration of both (acrylamide and bisacrylamide). $C$ denotes the percentage concentration of the crosslinker relative to the total concentration $T$. The mounted gels were allowed to polymerize overnight at room temperature. Electrophoresis of the samples was performed at room temperature. The initial running conditions were $30 \mathrm{~V}$ for 1-2 $\mathrm{h}$. After the samples had entered the stacking gel, electrophoresis was at $80 \mathrm{~V}$. Proteins were visualized by staining with silver nitrate.

\section{Hydroxyl radical production}

Hydroxyl radicals were measured by the method of Fukui et al. (1993). The basic reaction mixture contained $1 \mathrm{mg}$ of the partially-purified preparation, $3 \times$ $10^{-4} \mathrm{~mol}$ of dimethyl sulfoxide (DMSO), and $\mathrm{Na}$ acetate buffer $(40 \mathrm{mM}, \mathrm{pH} 4.5)$ in a total volume of 2 $\mathrm{ml}$ in a 33-ml test tube. Hydrogen peroxide $(3 \times$ $\left.10^{-6} \mathrm{~mol}\right), \mathrm{NADH}\left(3 \times 10^{-6} \mathrm{~mol}\right), \mathrm{NADH}$ plus su- peroxide dismutase (SOD) (0.3 mg, 2,670units $\mathrm{mg}^{-1}$ ), NADH plus catalase (0.3 mg, 42,000units $\left.\mathrm{mg}^{-1}\right), \mathrm{NADH}$ plus $N, N^{\prime}$-dimethyl-4-nitrosoaniline (DMNA) $\left(6 \times 10^{-6} \mathrm{~mol}\right)$, or ascorbic acid $\left(3 \times 10^{-6}\right.$ mol) were added to the basic reaction mixture. After $1.5 \mathrm{~h}$ of incubation at $30{ }^{\circ} \mathrm{C}$ under $100 \% \mathrm{O}_{2}$ or $\mathrm{N}_{2}, 1 \mathrm{ml}$ of $2 \%(w / v)$ Fast Yellow GC Salt reagent (Sigma Chemical Co., St. Louis, MO, USA) was added to the reaction mixture. The mixture was shaken and allowed to stand for $30 \mathrm{~min}$. Ethyl acetate $(10 \mathrm{ml})$ was added and the mixture was shaken well. After the ethyl-acetate layer was washed with distilled water (10 $\mathrm{ml}, 3$ times), $8 \mathrm{ml}$ of the ethyl-acetate layer was removed and evaporated off under reduced pressure. The residue was dissolved in ethyl acetate $(500 \mu \mathrm{l})$, filtered through a Millipore filter (pore size $0.2 \mu \mathrm{m}$ ), and analyzed by high-performance liquid chromatography as previously described (Lowry et al., 1951).

\section{Protein, amino acid, carbohydrate, and Fe analy- sis}

The protein concentration of the partially-purified preparation was determined by a modification of the method of Lowry et al. (1951). The amino acid composition was determined with an amino acid autoanalyzer (HITACHI, L-8500, Japan), following hydrolysis of the sample with $6 \mathrm{~N} \mathrm{HCl}$. The neutral carbohydrate content was determined by the phenolsulfuric acid assay (Dubois et al., 1956). Monosaccharide composition was measured with a saccharide composition analysis kit (Honen Corporation, Tokyo, Japan) according to the manufacturer's instructions. Following the hydrolysis of the sample, the released monosaccharides were coupled with $p$ aminobenzoic ethyl ester at the reducing end by reductive amination, according to the method of Yasuno et al. (1997). The p-aminobenzoic ethyl ester-derivatized monosaccharides were injected into a Honenpak $\mathrm{C} 18$ column $(75 \times 4.6 \mathrm{~mm}$ i.d., Honen Corp., Tokyo, Japan) and detected by fluorescence monitoring according to the method of Yasuno et al., 1997. Ferrous iron content was measured with ferrozine by the procedure of S $\phi$ rensen (1982).

\section{Fe (III) - and $\mathrm{Cu}$ (II) -reducing activity}

The reduction of $\mathrm{Fe}(\mathrm{III})$ to $\mathrm{Fe}(\mathrm{II})$ by the preparation was measured using ferrozine, according to the procedure of S $\phi$ rensen (1982). Distilled water $(500 \mu \mathrm{I})$, with or without $10 \mathrm{ppm} \mathrm{Fe} \mathrm{(III),} \mathrm{was}$ added to an aqueous solution of the partially-purified preparation (35 $\mu \mathrm{g}$ in $500 \mu \mathrm{l}$ ). For the control, an aqueous solution $(500 \mu \mathrm{I})$ containing $10 \mathrm{ppm} \mathrm{Fe}$ (II) or Fe (III) was added to distilled water (500 $\mu \mathrm{l})$. After $24 \mathrm{~h}$ of incubation at $30^{\circ} \mathrm{C}, 500 \mu \mathrm{l}$ of $1 \%$ 
ferrozine in distilled water was added. After the solutions were left standing for $24 \mathrm{~h}$ at $30^{\circ} \mathrm{C}$, their absorption spectra were measured at $400 \mathrm{~nm}$ to $750 \mathrm{~nm}$ with a spectrophotometer. The $\mathrm{Cu}$ (II) reducing ability of the preparation was measured by the method of Somogyi-Nelson (Somogyi, 1951).

\section{Determination of carbonyl groups}

The carbonyl groups, other than those in the peptide bonds, were assayed by the method described in Uchida et al. (1998). Distilled water $(500 \mu \mathrm{l})$, with or without $3.5 \mathrm{mg}$ of sample, was added to $0.1 \%(\mathrm{w} / \mathrm{V})$ 2,4-dinitrophenylhydrazine in $2 \mathrm{~N} \mathrm{HCl}$. After $1 \mathrm{~h}$ at room temperature, $500 \mu \mathrm{l}$ of $20 \%(\mathrm{~W} / \mathrm{v})$ trichloroacetic acid (TCA) was added to each assay. Following centrifugation at $9,500 \times g$ for $10 \mathrm{~min}$, the supernatants were scanned at $800 \mathrm{~nm}$ to $300 \mathrm{~nm}$. The number of carbonyl groups was calculated based on the rate of decrease in absorbance at $365 \mathrm{~nm}$.

\section{Determination of aldehyde groups}

Aldehyde groups in the preparation were assayed using methone (dimethyldihydroresorcin). Distilled water $(1 \mathrm{ml})$, with or without $10 \mathrm{mg}$ of the sample, was mixed with $100 \mu \mathrm{l}$ of $0.1 \mathrm{M}$ methone in methanol and shaken vigorously for $30 \mathrm{~min}$. Controls contained $100 \mu \mathrm{l}$ of $0.1 \mathrm{M}$ methone and $1 \mathrm{ml}$ aqueous solution of $0.012 \mathrm{M}$ formaldehyde or $0.012 \mathrm{M}$ 2,4dihydroxybenzaldehyde. The mixtures were extracted with $1 \mathrm{ml}$ ethyl acetate. Methone in the ethyl acetate fraction was measured directly by gas chromatography at $160{ }^{\circ} \mathrm{C}$ in the isothermal mode using a glass column packed with 3\% OV-101 on chromsorb $Q$ 100/120 (Applied Science, Japan). The number of aldehyde groups was calculated based on the loss of methone.

\section{Determination of protein glycosylation}

Glycosylation of the $\mathrm{N}$-terminal and side-chain amino acids in the glycopeptide was measured by the thiobarbituric acid (TBA) colorimetric technique of Fluckiger and Gallop (1984). Following the addition of $500 \mu \mathrm{l}$ of $0.5 \mathrm{M}$ oxalic acid to $1-\mathrm{ml}$ aqueous solutions containing $0,1 \mathrm{mg}$, or $2 \mathrm{mg}$ of the sample, or 25 $\mu \mathrm{mol}$ of cellobiose (8.6mg), glucose (4.5mg), galactose $(4.5 \mathrm{mg})$, or mannotriose $(12.6 \mathrm{mg})$, the tubes were mixed and capped with rubber stoppers vented with 26-gauge needles. The tubes were placed in a heating block at $100{ }^{\circ} \mathrm{C}$ and the needles were removed after a 10 -min equilibration period. After $5 \mathrm{~h}$, the tubes were cooled in an ice bath. The volumes of the solutions were adjusted with water to $1.5 \mathrm{ml}$. Cold $40 \%(\mathrm{w} / \mathrm{v})$ TCA $(500 \mu \mathrm{l})$ was added to each tube and the tubes were mixed and centrifuged at $9,500 \times g$ for $4 \mathrm{~min}$. A $500 \mu \mathrm{l}$ aliquot of the supernatant was removed and $500 \mu \mathrm{l}$ of a $0.05 \mathrm{M}$ aqueous 2-thiobarbituric acid solution was added. The solutions were incubated at $37{ }^{\circ} \mathrm{C}$ for $15 \mathrm{~min}$ and at room temperature for $20 \mathrm{~min}$. The absorption spectra were measured at $400 \mathrm{~nm}$ to $700 \mathrm{~nm}$. The standard curves were prepared using the $\mu \mathrm{mol}$ range of 5hydroxymethylfurfural (5-HMF) and $500 \mu \mathrm{l}$ of a 0.05 $M$ aqueous TBA.

\section{RESULTS AND DISCUSSION}

\section{Partial purification of the extracellular substance}

The Sephadex G-50 gel-filtration chromatography of the acetone precipitate of the extracellular fluid from 30-day-old F. palustris cultures was carried out. Only one major peak of one-electron-oxidation activity, as measured by ethylene generation from KTBA, was observed in the low-molecular-weight fractions (1000-5000). This peak corresponded to the maximum absorbance peak at $280 \mathrm{~nm}$. The major peak was pooled and lyophilized. Then the Sephadex G-25 gel-filtration chromatography of this pooled material was carried out. Low molecular-weight fractions (1000-5000), constituting the major peak of the oneelectron-oxidation activity, were pooled, lyophilized, and subjected to anion exchange chromatography on HiPrep 16/10 DEAE FF. Fractions, constituting the major peak of the one-electron-oxidation activity were pooled, desalted, and lyophilized. The yield of this partially-purified preparation was $50 \mathrm{mg}$ from 10030 ml, 30-day-old cultures of $F$. palustris.

\section{Composition and molecular weight}

The molecular weight of the partially-purified preparation, as determined by gel-filtration on Sephadex G25 or Sephadex G-50, was in the range of 1,0005,000 (data not shown). Tricine-SDS-PAGE of the partially-purified preparation yielded two bands of 7.2 $\mathrm{kDa}$ and $10.0 \mathrm{kDa}$. The partially purified preparation was $42 \%$ neutral carbohydrate by weight and $54 \%$ protein by weight. The true molecular weight of the preparation could be lower than $7.2 \mathrm{kDa}$ and 10,0 $\mathrm{kDa}$ because molecular weights of glycopeptides determined by SDS-PAGE are higher than their true molecular weights (Leach et al., 1980).

\section{Hydroxyl radical generation}

The transformation of DMSO to methane sulfuric acid is a specific assay for $\cdot \mathbf{O H}$ (Hirano et al., 1997). The generation of $\cdot \mathrm{OH}$ by the partially-purified glycopeptide in the presence of the electron donor $\mathrm{NADH}\left(3 \times 10^{-6} \mathrm{~mol}\right)$ under a $100 \% \mathrm{O}_{2}$ atmosphere $\left(9.2 \times 10^{-8} \mathrm{~mol} \mathrm{ml}^{-1} 1.5 \mathrm{~h}^{-1}\right)$ was given a relative 
value of $100 \%$ (Table 1). In the absence of $\mathrm{H}_{2} \mathrm{O}_{2}$ or an electron donor such as $\mathrm{NADH}$ or ascorbic acid, only a very small amount of $\cdot \mathrm{OH}$ was generated under $100 \% \mathrm{O}_{2}$ and almost no $\cdot \mathrm{OH}$ was generated under an $\mathrm{N}_{2}$ atmosphere. In the presence of $\mathrm{NADH}$ or ascorbic acid under $100 \% \mathrm{O}_{2}, \cdot \mathrm{OH}$ generation was 15-fold and 47-fold higher, respectively, than in the absence of an electron donor. In the presence of $\mathrm{NADH}$, under $100 \% \mathrm{O}_{2}$, catalase almost completely blocked $\cdot \mathrm{OH}$ generation, and the $\cdot \mathrm{OH}$-scavenging agent DMNA suppressed $\cdot \mathrm{OH}$ generation. Likewise, SOD inhibited $\cdot \mathrm{OH}$ generation in the presence of $\mathrm{NADH}$ by about $40 \%$ (Table 1). These results indicate that the extracellular glycopeptide from $F$. palustris catalyzes redox reactions between electron donors such as NADH or ascorbic acid and $\mathrm{O}_{2}$ to produce $\mathrm{H}_{2} \mathrm{O}_{2}$ via superoxide and further reduces $\mathrm{H}_{2} \mathrm{O}_{2}$ to $\cdot \mathrm{OH}$. We previously demonstrated that the production of $\cdot \mathrm{OH}$ in $F$. palustris cultures is related to the degradation rates of wood, crystalline cellulose, and ligninmodel compounds in the cultures (Hirano et al., 1997).

\section{Amino acid, monosaccharide, and Fe content}

Amino acid analysis of the partially-purified preparation indicates that it contains $10.4 \%$ aspartic acid, 9.1\% glutamic acid, 1.3\% lysine, and 25.1\% $\mathrm{NH}_{3}$ (Table 2). Thus the substance contains an abundance of amino acids with side-chain amino groups.

The glycopeptide contains unusually high levels of galactose $(47 \%)$, glucose $(22 \%)$, and xylose (18\%); whereas there is less than $1 \% N$-acetyl-Dglucosamine and a negligible amount of $N$-acetyl- $D$ galactosamine (Table 3 ). In glycopeptides, $N$-acetyl$D$-glucosamine usually combines with the side-chain amino group of asparagine and $N$-acetyl-D-

TABLE 1. Generation of the hydroxyl radical by the partially-purified glycopeptide isolated from wood-degrading cultures of Fomitopsis palustris. ${ }^{a}$

\begin{tabular}{lccc}
\hline Addition to reaction mixture & Atmosphere & $\begin{array}{c}\times 10^{-8} \mathrm{~mol}^{-1} \\
\mathrm{ml}^{-1}\end{array}$ & $\begin{array}{c}\text { Relative } \\
\text { value (\%) }\end{array}$ \\
\hline None & $100 \% \mathrm{O}_{2}$ & 0.6 & 6 \\
None & $100 \% \mathrm{~N}_{2}$ & 0.3 & 3 \\
$3 \times 10^{-6} \mathrm{~mol} \mathrm{H} \mathrm{O}_{2}$ & $100 \% \mathrm{~N}_{2}$ & 4.0 & 44 \\
$3 \times 10^{-6} \mathrm{~mol} \mathrm{NADH}$ & $100 \% \mathrm{O}_{2}$ & 9.2 & 100 \\
$3 \times 10^{-6} \mathrm{~mol} \mathrm{NADH}, 0.3 \mathrm{mg} \mathrm{SOD}{ }^{d}$ & $100 \% \mathrm{O}_{2}$ & 3.6 & 39 \\
$3 \times 10^{-6} \mathrm{~mol} \mathrm{NADH}, 0.3 \mathrm{mg}$ catalase & $100 \% \mathrm{O}_{2}$ & 0.9 & 10 \\
$3 \times 10^{-6} \mathrm{~mol} \mathrm{Ascorbic} \mathrm{acid}$ & $100 \% \mathrm{O}_{2}$ & 28.2 & 307 \\
$3 \times 10^{-6} \mathrm{~mol} \mathrm{NADH}, 6 \times 10^{-6}$ mol DMNA & $100 \% \mathrm{O}_{2}$ & 3.3 & 36 \\
\hline
\end{tabular}

${ }^{a}$ Reaction mixtures contained $1.0 \mathrm{mg}$ of the preparation, $3 \times 10^{-4} \mathrm{~mol} \mathrm{DMSO}$, and acetate buffer $(40 \mathrm{mM}, \mathrm{pH} 4.5)$ in a total volume of $2 \mathrm{ml}$. Reactions and detection of methane sulfuric acid were as described in the text.

${ }^{b}$ Reaction mixtures were incubated under $100 \% \mathrm{O}_{2}$ or $\mathrm{N}_{2}$, as described in the text.

'Each value represents the average of triplicate assays.

${ }^{d}$ Superoxide dismutase, 2,670unit/mg.

TABLE 2. Amino acid composition of the partially-purified glycopeptide isolated from wooddegrading cultures of $F$. palustris. ${ }^{a}$

\begin{tabular}{cccc}
\hline Amino acids & $\%$ & Amino acids & $\%$ \\
\hline Asparagine & $\mathrm{ND}^{b}$ & Tryptophan & $\mathrm{ND}$ \\
Asparatic acid & 10.4 & Threonine & 8.9 \\
Alanine & 7.8 & Valine & 3.6 \\
Arginine & 1.1 & Histidine & 0.4 \\
Isoleucine & 3.2 & Phenylalanine & 3 \\
Glycine & 7.1 & Proline & $\mathrm{ND}$ \\
Glutamine & $\mathrm{ND}$ & Methionine & $\mathrm{ND}$ \\
Glutamic acid & 9.1 & Lysine & 1.3 \\
Cysteine & $\mathrm{ND}$ & Leucine & 5.4 \\
Serine & 9.6 & $\mathrm{NH}_{3}$ & 25.1 \\
Tyrosine & 3.7 & & \\
\hline
\end{tabular}

${ }^{a}$ Determined with an amino acid autoanalyzer, following hydrolysis of the sample with $6 \mathrm{~N} \mathrm{HCl}$. ${ }^{b} \mathrm{ND}$ : Not detectable. 
TABLE 3. Monosaccharide composition of the partiallypurified glycopeptide isolated from wood-degrading cultures of $F$. palustris. ${ }^{a}$

\begin{tabular}{lr}
\hline \multicolumn{1}{c}{ Monosaccharide } & $\%^{b}$ \\
\hline Galactose & 47 \\
Mannose & 8 \\
Glucose & 22 \\
Arabinose & 4 \\
Xylose & 18 \\
$N$-acetyl-D-glucosamine & 1 \\
$N$-acetyl-D-galactosamine & 0 \\
\hline
\end{tabular}

${ }^{a}$ Monosaccharide composition was determined using a saccharide composition analysis kit, as described in the text.

${ }^{b}$ Percentage of total monosaccharides.

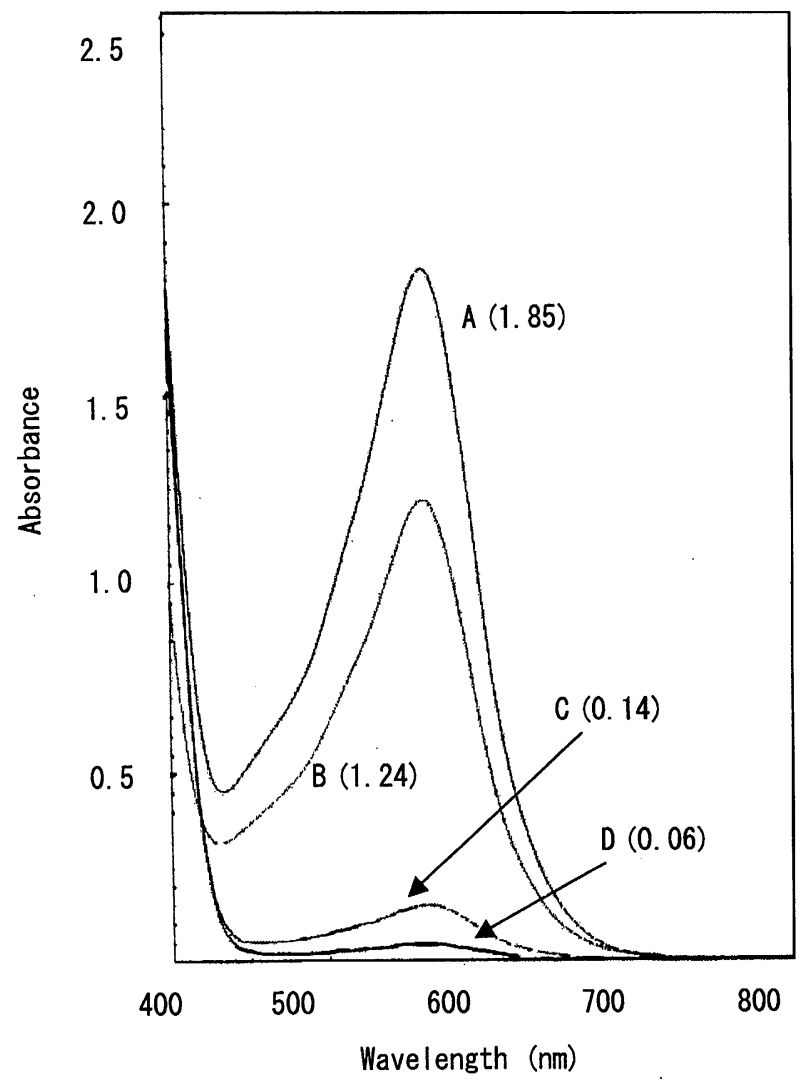

FIG. 1. Fe (III) reduction by the partially-purified extracellular glycopeptide from Fomitopsis palustris cultures. Absorption spectra were determined at 400 to $750 \mathrm{~nm}$. Fe (III) reduction was measured using $1 \%$ ferrozine, according to the procedure of S申rensen (1982), as described in the text. A: 10/3 ppm Fe (II); B: 10/3 ppm Fe(III), $35 \mu \mathrm{g}$ glycopeptide sample; C: $10 / 3 \mathrm{ppm}$ Fe(III); D: $35 \mu \mathrm{g}$ glycopeptide sample. Numbers in parentheses indicate the absorbance at $560 \mathrm{~nm}$ galactosamine combines with the $\mathrm{OH}$ side chains of serine or threonine. These results suggest that carbohydrates other than $\mathrm{N}$-acetyl-D-glucosamine and $\mathrm{N}$ acetyl-D-galactosamine are attached to the side-chain amino groups in this glycopeptide.

The partially-purified glycopeptide contained $0.06 \%$ ferrous iron by weight, as determined with ferrozine.

\section{Fe (III) - and Cu (II) -reducing activity}

The ferric-iron-reducing activity of the partiallypurified glycopeptide was measured using ferrozine (Fig. 1, Table 4). Fig. 1 shows that $1 \mathrm{mg}$ of the glycopeptide reduced about $1.7 \mu \mathrm{mol}$ of $\mathrm{Fe}$ (III) to $\mathrm{Fe}(\mathrm{II})$; that is, a single mole of the glycopeptide reduced about 17 moles of $\mathrm{Fe}$ (III) to Fe (II), assuming that the molecular weight is 10,000 .

The $\mathrm{Cu}(\mathrm{II})$-reducing activity of the glycopeptide, measured by the method of Somogyi-Nelson, was 1.3 $\mu \mathrm{mol} / \mathrm{mg}$ (Table 4).

\section{Carbonyls}

The carbonyl groups in the glycopeptide, excepting those in the peptide bonds, were determined with 2,4dinitrophenylhydrazine, which combines with carbonyl groups, with the loss of water, to form 2,4dinitrophenylhydrazone, which is insoluble in water. The number of carbonyl groups is calculated based on the decrease in absorbance at $365 \mathrm{~nm}$. Carbonyl groups were present $0.6 \mu \mathrm{mol} \mathrm{mg}^{-1}$ in the glycopeptide (Table 4).

The aldehyde groups in the glycopeptide were determined using methone, which readily condenses stoichiometrically with aldehyde groups but not with ketones. Aldehyde groups were present in the glycopeptide at less than $3 \times 10^{-9} \mu \mathrm{mol} \mathrm{mg}^{-1}$ or 0.04 $\mathrm{mol} \mathrm{mol}^{-1}$ (Table 4). This suggests that most of the

TABLE 4. Fe (III)- and Cu (II)-reducing activities and carbonyl and aldehyde content of the partially-purified glycopeptide isolated from wood-degrading cultures of $F$. palustris.

\begin{tabular}{|c|c|c|}
\hline & $\mu \mathrm{mol} \mathrm{mg}^{-1}$ & $\mathrm{~mol} 10^{-4} \mathrm{~g}^{-1}$ \\
\hline $\mathrm{Fe}(\mathrm{III})$ reduction $^{a}$ & 1.7 & 17 \\
\hline $\mathrm{Cu}(\mathrm{II})$-reduction ${ }^{b}$ & 1.3 & 13 \\
\hline Carbonyl groups ${ }^{c}$ & 0.6 & 6 \\
\hline Aldehyde groups ${ }^{d}$ & negligible & negligible \\
\hline 1-amino-2-ketoses ${ }^{e}$ & 0.5 & 5 \\
\hline
\end{tabular}

${ }^{a}$ Determined using $1 \%$ ferrozine, according to the procedure of Sфrensen, as described in the text.

${ }^{b}$ Determined by the method of Somogyi-Nelson.

'Determined using 2,4-dinitrophenylhydrazine method of Uchida et al. as described in the text.

${ }^{d}$ Assayed using methone, as described in the text. 
carbonyl groups in the glycopeptide are ketone or enediol groups rather than aldehydes. However 0.6 $\mu \mathrm{mol}$ of $\alpha$-hydroxyketone per $\mathrm{mg}$ of glycopeptide could reduce, at most, only $1.2 \mu \mathrm{mol}$ of $\mathrm{Fe}(\mathrm{III})$, less than the measured $\mathrm{Fe}(\mathrm{II})$ reduction of $1.7 \mu \mathrm{mol}$ per $\mathrm{mg}$ of glycoprotein (Table 4).

\section{Glycosylation}

Glycosylation of the N-terminal and the side-chain amino groups in the glycopeptide was measured using the TBA method. In the TBA colorimetric method, 1-amino-2-deoxyketoses are dehydrated in boiling oxalic acid and released as 5-HMF. The sugar-free protein is removed by TCA precipitation and the 5HMF concentration is determined colorimetrically after condensation with TBA (Furth, 1988). One mg of the glycopeptide produced about $0.5 \mu \mathrm{mol}$ of 5 HMF, whereas $25 \mu \mathrm{mol}$ of cellobiose $(8.6 \mathrm{mg}$ ) produced $0.11 \mu \mathrm{mol}$ of 5 -HMF (Fig. 2). Glucose and galactose (25 $\mu$ mole, $4.5 \mathrm{mg}$ ) each formed 0.06 $\mu \mathrm{mol}$ of 5 -HMF. Mannotriose (25 $\mu \mathrm{mol}, 12.6 \mathrm{mg}$ ) produced $0.15 \mu \mathrm{mol}$ of 5 -HMF (data not shown). These results suggest that under the acidic conditions polysaccharides were dehydrated in very low yields and were hydrolyzed in high yields (or were hydrolyzed in high yields and were hydrated in very low yields) to $5-\mathrm{HMF}$ in less than $0.3 \%$ yields. Thus, most of the 5-HMF produced from the partially-purified preparation came from the carbohydrates condensing with the N-terminal and side-chain amino groups in the glycopeptide. The mole number of side-chain amino groups condensing with carbohydrates to form the glycopeptide could be larger than $0.5 \mu \mathrm{mol} m$ $\mathrm{g}^{-1}$, since 5-HMF formation from $\mathrm{N}$ - and O-glycosides also is small under acidic conditions (Fluckiger and Gallop, 1984).

Side-chain amino groups in proteins condense with carbohydrate aldehyde groups to yield glycosylamines (Schiff bases), which undergo nucleophilecatalyzed rearrangements to form 1-amino-1-deoxy$D$-fructose derivatives (Amadori compounds). These compounds reduce $\mathrm{O}_{2}$ to $\mathrm{H}_{2} \mathrm{O}_{2}$ and $\mathrm{Fe}$ (III) to $\mathrm{Fe}(\mathrm{II})$ (Oak et al., 2000). Thus, iron-containing glycosylated peptides could reduce $\mathrm{O}_{2}$ to $\cdot \mathrm{OH}$ via $\mathrm{H}_{2} \mathrm{O}_{2}$ as shown in Fig. 3.

\section{Proposed mechanism for wood decay by brown- rot fungi}

On the basis of earlier findings and the results presented here, we propose the following mechanism for wood decay by brown-rot fungi: Fungal hyphae in the wood cell lumen secrete a glycosylated peptide of lower than $10,000 \mathrm{Da}$. This effector is able to diffuse through the $S_{3}$ layer into the $S_{2}$ layer and middle

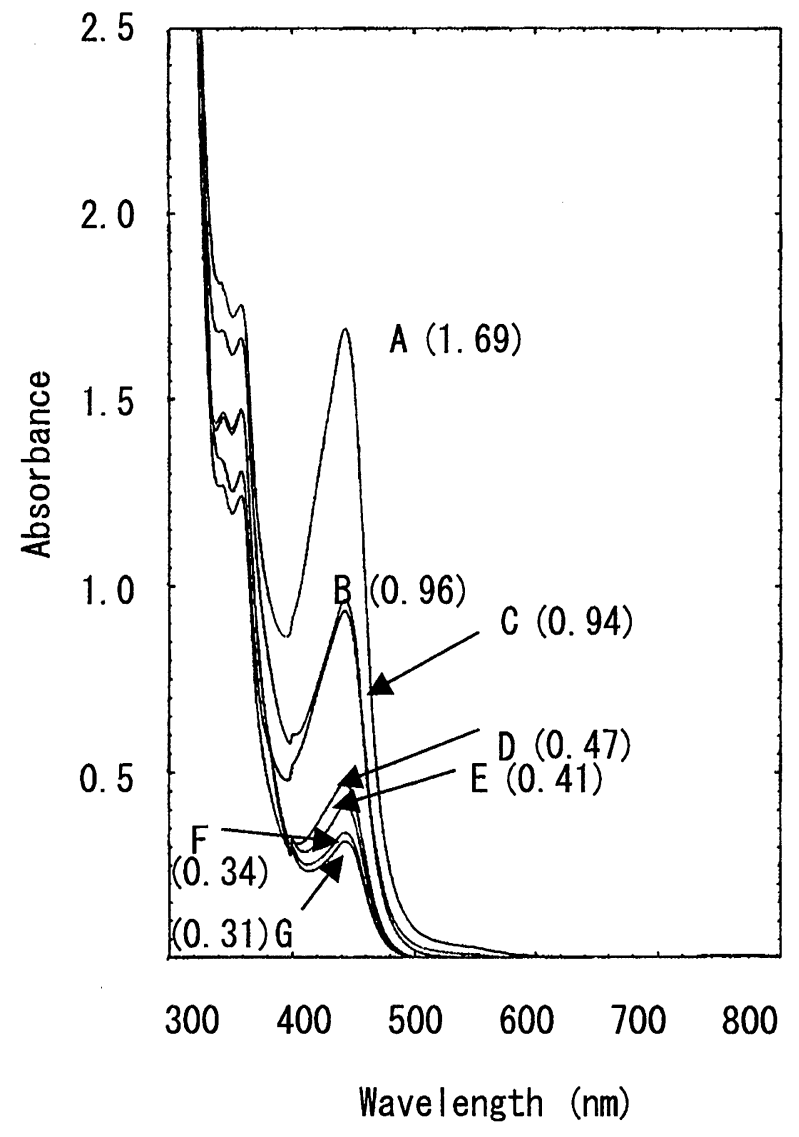

FIG. 2. Absorption spectra of 5-HMF produced from TBA and the carbohydrate released from the partially-purified extracellular glycopeptide from $F$. palustris cultures. Experimental procedures were as described in the text. A: $0.5 \mathrm{mg}$ of the glycopeptide per $\mathrm{ml}$; $\mathrm{B}: 0.25 \mathrm{mg}$ of the glycopeptide per ml; C: $0.125 \mu \mathrm{mol}$ of 5 -HMF per ml; D: $0.125 / 2 \mu \mathrm{mol}$ of 5-hydroxymethylfurfural per ml; $\mathrm{E}: 8.6 \mathrm{mg}$

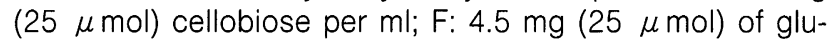
cose per ml; G: $4.5 \mathrm{mg}(25 \mu \mathrm{mol})$ of galactose per $\mathrm{ml}$.

lamella of the cell wall, where it reduces $\mathrm{Fe}(\mathrm{III})$ to $\mathrm{Fe}$ (II) and chelates $\mathrm{Fe}(\mathrm{II})$. Alternatively it may reduce $\mathrm{Fe}$ (III) and chelate Fe (II) prior to diffusion into the $\mathrm{S}_{3}$ layer. The glycopeptide with $\mathrm{Fe}(\mathrm{II})$ catalyzes redox reactions between $\mathrm{O}_{2}$ and an electron donor to produce $\cdot \mathrm{OH}$ via $\mathrm{H}_{2} \mathrm{O}_{2}$ as shown in Fig. 3. The $\cdot \mathrm{OH}$ attacks cell wall constituents, causing the depolymerization of both crystalline and noncrystalline cellulose. The $\cdot \mathrm{OH}$ also attacks the lignin in the cell wall, causing a variety of reactions. These processes transform the cell wall by cutting channels through the $S_{3}$ layer for enzyme diffusion. Enzymes, including endoglucanases, then can penetrate the cell wall and act on hemicellulose and noncrystalline regions of the cellulose that have been attacked by $\cdot \mathrm{OH}$.

Reactions caused by the attack of $\cdot \mathrm{OH}$ on lignin, including the hydroxylation of aromatic rings, demethylation of methoxyl groups on aromatic rings, and 


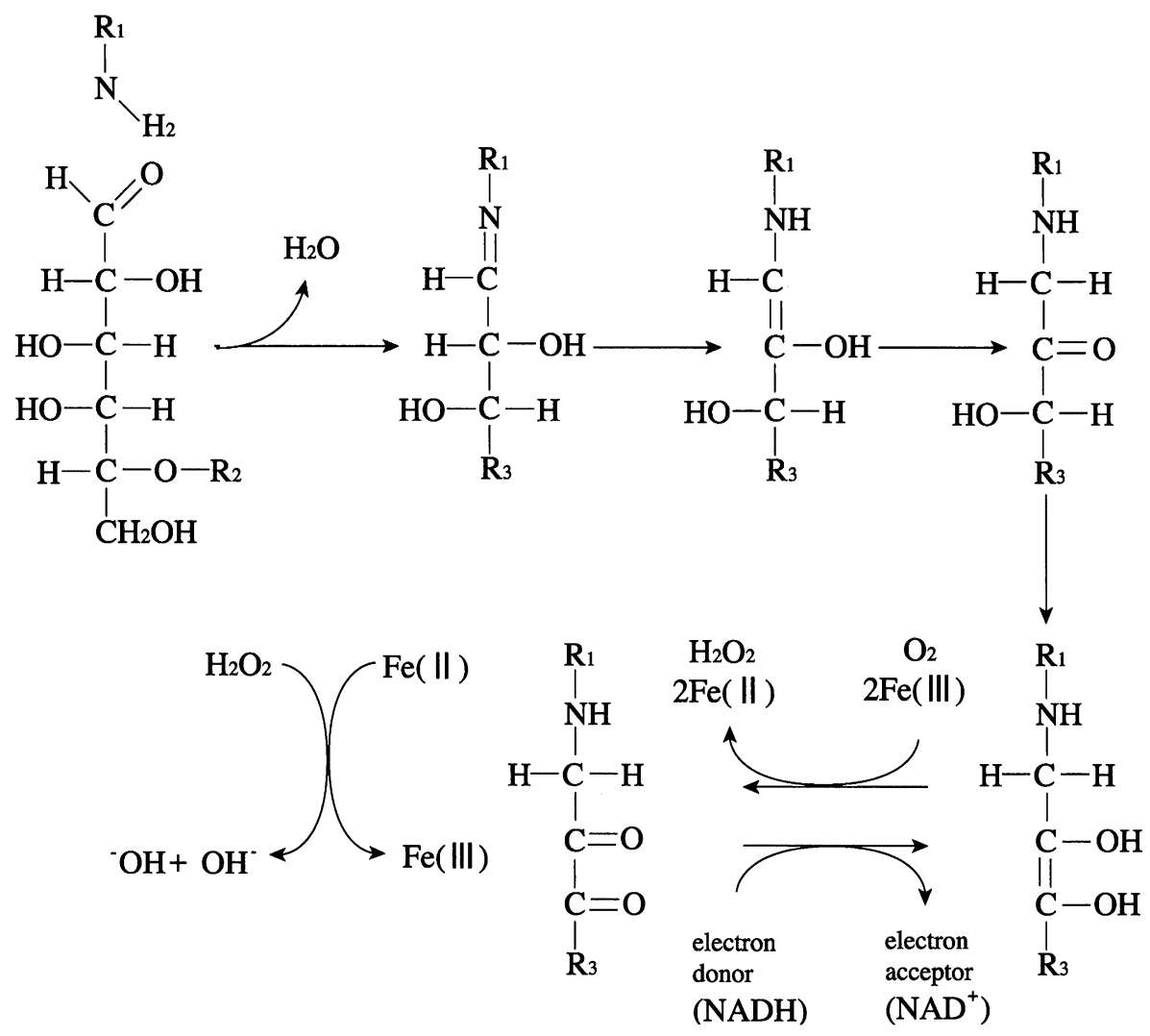

FIG. 3. Proposed mechanism for the generation of $\cdot \mathrm{OH}$ and the reduction of $\mathrm{Fe}$ (III) to $\mathrm{Fe}$ (II) by the extracellular glycosylated peptide from F. palustris.

$\beta-0-4$ alkyl aryl ether-cleavage, produce a significant number of dihydroxy aromatic structures (Filley et al., 2002; Henriksson et al., 2000). These dihydroxy aromatic structures could reduce $\mathrm{O}_{2}$ to $\mathrm{H}_{2} \mathrm{O}_{2}, \mathrm{Fe}$ (III) to $\mathrm{Fe}(\mathrm{II})$, and the oxidized form of the glycopeptide to the reduced form (Jensen Jr. et al., 2001; Paszczynski et al., 1999).

The reaction of $\cdot \mathrm{OH}$ with saccharides is initiated by hydrogen subtraction, followed, under aerated conditions, by oxidative $\mathrm{C}-\mathrm{C}$ cleavage, which can cause depolymerization of saccharides and the formation of new aldehyde compounds (Uchida and Kawakishi, 1988). This series of reactions produces superoxide, which reduces $\mathrm{Fe}(\mathrm{III})$ to $\mathrm{Fe}(\mathrm{II})$ or generates $\mathrm{H}_{2} \mathrm{O}_{2}$ by either non-enzymatic or SOD-catalyzed dismutation. Some of the newly-produced aldehydes also may reduce $\mathrm{Fe}$ (III).

The ongoing production of $\cdot \mathrm{OH}$ by the glycopeptide in wood cell walls requires a constant supply of $\mathrm{O}_{2}$ and an electron donor for the reduction of the oxidized form of the glycopeptide. The identification of the electron donor will be the subject of further investigation.

\section{REFERENCES}

Chirat, C., and Lachenal, D. (1997) Effect of hydroxyl radicals on cellulose and pulp and their occurrence during ozone bleaching. Holzforschung, 51, 147-154.

Dubois, M., Gilles, K. A., Hamilton, J. K., Rebers, P. A., and Smith, F. (1956) Colorimetric method for determination of sugars and related substances. Anal. Chem., 28, 350356.

Enoki, A., Tanaka, H., and Fuse, G. (1988) Degradation of lignin-related compounds, pure cellulose, and wood components by white-rot and brown-rot fungi. Holzforschung, 42, 85-93

Enoki, A., Tanaka, H., and Fuse, G. (1989) Relationship between degradation of wood and production $\mathrm{H}_{2} \mathrm{O}_{2}$ producing or one-electron oxidases by brown-rot fungi. Wood Sci. Technol., 23, 1-12.

Enoki, A., Hirano, T., and Tanaka, H. (1992) Extracellular substance from the brown-rot basidiomycete Gloeophyllum trabeum that produces and reduces hydrogen peroxide. Mater. Org., 27, 247-261.

Espejo, E., Agosin, E., and Vicuna, R. (1990) Catabolism of 1,2-diarylethane lignin model compounds by two brownrot fungi. Arch. Microbiol., 154, 370-374.

Filley, T. R., Cody, G. D., Goodell, B., Jellison, J. Noser, and C. Ostrofsky, A. (2002) Lignin demethylation and polysaccharide decomposition in spruce sapwood degraded by brown rot fungi. Org.Geochem., 33, 111-124. 
Fukui, S., Hanasaki, Y., and Ogawa, S. (1993) Highperformance liquid chromatographic determination of methanesulphinic acid as a method for the determination of hydroxyl radicals. J. Chromatogr., 630, 187-193.

Flournoy, D. S., Kirk, T. K., and Highley, T. L. (1991) Wood decay by brown-rot fungi: Change in pore structure and cell wall volume. Holzforschung, 45, 383-388.

Fluckiger, R., and Gallop, P. M. (1984) Measurement of nonenzymatic protein glycosylation. Methods in Enzymol., 106, 77-87.

Gierer, J., Yang, E., and Reitberger, T. (1992) The reactions of hydroxyl radicals with aromatic rings in lignins, studied with creosol and 4-methylveratrol. Holzforschung, 46, 495-504.

Henriksson, G., Johansson, G., and Pettersson, G. (2000) A critical review of cellobiose dehydrogenases. J. Biotechnol., 78, 93-113.

Highley, T. L., and Murmanis, L. L. (1985) Determination of hydrogen peroxide production in Coriolus versicolor and Poria placenta during wood degradation. Mater. Org., 20, 241-251.

Highley, T. L. (1987) Changes in chemical components of hardwood and softwood by brown-rot fungi. Mater. Org., 22, 39-45.

Hirano, T., Tanaka, H., and Enoki, A. (1995) Extracellular substance from the brown-rot basidiomycete Tyromyces palustris that reduces molecular oxygen to hydroxyl radicals and ferric iron to ferrous iron. Mokuzai Gakkaishi,41, 334-341.

Hirano, T., Tanaka, H., and Enoki, A. (1997) Relationship between production of hydroxyl radicals and degradation of wood by the brown-rot fungus, Tyromyces palustris. Holzforschung, 51, 389-395.

Hirano, T., Enoki, A., and Tanaka, H. (2000) Immunogold labeling of an extracellular substance producing hydroxyl radicals in wood degraded by brown-rot fungus Tyromyces palustris. J. Wood Sci., 46, 45-51.

Jensen, JR. K. A., Houtman, C. J., Ryan, Z. C., and Hammel, K. E. (2001) Pathways for extracellular Fenton chemistry in the brown rot Basidiomycete Gloeophyllum trabeum. Appl. Environ. Microbiol., 67, 2705-2711.

Kuo, M., Stokke, D. D., and McNabb, H. S. (1988) Microscopy of progressive decay of cottonwood by the brown-rot fungus Gloeophyllum trabeum. Wood Fiber Sci., 20, 405-414.

Leach, B. S., Collawn, J. F., and Fish, W. W. (1980) Behavior of glycopeptides with empirical molecular weight estimation methods. 1. In Sodium Dodecyl Sulfate. Biochemistry, 19, 5734-5741.

Lowry, H., Rosebrough, N. J., Farr, A. L., and Randall, R. J. (1951) Protein measurements with the Follin phenol reagent. J. Biol. Chem., 193, 265-275.

Oak, J-H., Nakagawa, K.; and Miyazawa, T. (2000) Synthetically prepared Amadori-glycated phosphatidylethanolamine can trigger lipid peroxidation via free radi- cal reactions. FEBS Lett., 481, 26-30.

Paszczynski, A., Crawford, R., Funk, D., and Goodell, B. (1999) De Novo synthesis of 4,5-dimethoxycatechol and 2,5-dimethoxyhydroquinone by the brown-rot fungus Gloeophyllum trabeum. Appl. Environ. Microbiol., 65, 674-679.

Rättö, M., Ritschkoff A-C., and Viikari, L. (1997) The effect of oxidative pretreatment on cellulose degradation by Poria placenta and Trichoderma reesei cellulase. Appl. Microbiol. Biotechnol., 48, 53-57.

Schägger, H., and von, Jagow, G. (1987) Tricine-sodium dodecyl sulfate-polyacrylamide gel electrophoresis for the separation of proteins in the range from 1 to $100 \mathrm{kDa}$. Anal. Biochem., 166, 368-379.

Somogyi, M. (1951) Note on sugar determination. J. Biol. Chem., 195, 19-23.

S $\phi$ rensen, J. (1982) Reduction of ferric iron in anaerobic, marine sediment and interaction with reduction of nitrate and sulfate. Appl. Environ. Microbiol., 43, 319-324.

Srebotnik, E., and Messner, K. (1991) Immunoelectron microscopical study of the porosity of brown-rot degraded pine wood. Holzforschung, 45, 95-101.

Uchida, K., Kanematsu, M., Sakai, K., Matsuda, T., Hattori, N., Mizuno, Y., Suzuki, D., Miyata, T., Noguchi, N., Niki, E., and Osawa, T. (1998) Protein-bound acrolein: potential markers for oxidative stress. Proc. Natl. Acad. Sci. USA, 95, 4882-4887.

Uchida, K., and Kawakishi, S. (1988) Interaction of $(1 \rightarrow 4)$ and $(1 \rightarrow 6)$ - linked disaccharides with the Fenton reagent under physiological conditions. Carbohydr. Res., 173, 8999.

Wang, W., and Gao, P. J. (2003) Function and mechanism of a low-molecular-weight peptide produced by Gloeophyllum trabeum in biodegradation of cellulose. J. Biotechnol., 101, 119-130.

Wang, W. T., LeDonne, Jr. N. C., Ackerman, B., and Sweeley, C. C. (1984) Structural characterization of oligosaccharides by high-performance liquid chromatography, fast-atom bombardment-mass spectrometry, and exoglycosidase digestion. Anal. Biochem., 141, 366-381.

Yasuno, S., Murata, T., Kokubo, K., Yamaguchi, T., and Kamei, M. (1997) Two-mode analysis by highperformance liquid chromatography of $p$-aminobenzoic ethyl ester-derivatized monosaccharides. Biosci. Biotech. Biochem., 61, (11), 1944-1946.

Zohar, K., Jensen, K. A., and Hammel, K. E. (1999) Biodegradative mechanism of the brown rot basidiomycete Gloeophyllum trabeum: evidence for an extracellular hydroquinone-driven Fenton reaction. FEBS Lett., 446, 49-54.

Zohar, K., Bao, W., and Hammel, K. E. (1998) Rapid polyether cleavage via extracellular one-electron oxidation by a brown-rot basidiomycete. Proc. Natl. Acad. Sci. USA, 95, 10373-10377. 